Tetrahedron

journal homepage: www.elsevier.com

\title{
One-pot synthesis of pyrroles using a titanium-catalyzed multicomponent coupling procedure
}

\author{
Cody Pasko, Amila A. Dissanayake, Brennan S. Billow and Aaron L. Odom*
}

Michigan State University, Department of Chemistry, 578 S. Shaw Ln, East Lansing, MI 48824

\section{ARTICLE INFO}

\section{Article history:}

Received

Received in revised form

Accepted

Available online

Keywords:

pyrrole; catalysis; multicomponent reaction; titanium
ABSTRACT

A simple one-pot procedure for the production of 2-carboxylpyrroles with 4-alkyl, 5-alkyl, 4aryl, 4-aryl-5-alkyl, or 3,4-diaryl substitution patterns is presented. The procedure involves the titanium-catalyzed multicomponent coupling of alkynes, primary amines and isonitriles to give 1,3-diimines in situ; the multicomponent product is then treated with the ethyl ester of glycine hydrochloride to give the $\mathrm{NH}$-pyrrole. The reaction can be carried out with the neutralized glycine ester or with the hydrochloride salt using DBU as a base. Yields of pyrrole based on starting alkyne varied from $25-65 \%$ over the one pot procedure, and in most cases only one regioisomer of the product is observed. Further, it is proposed that the regioselectivities of the reactions are a result of rate-determining ring closure after relatively fast transimination with glycine ethyl ester.

2015 Elsevier Ltd. All rights reserved.

* e-mail: odom@chemistry.msu.edu 


\section{Introduction}

Multicomponent Reactions (MCR) allow tremendous diversity from simple starting materials in a minimum of steps. Ideally, the reactants will be inexpensive, using abundant elements as well. Recently, we have developed synthetic protocols for the synthesis of many different heterocyclic systems. These syntheses rely on Earth-abundant, and inexpensive titanium to catalyze an MCR that provides useful tautomers of 1,3-diimines. One-pot reaction of these MCR products with a cyclizing agent provides pyrazoles, quinolines, pyrimidines, isoxazoles, or pyridines. $^{1,2}$

In this report, we describe conditions for the production of 2carboxylpyrrole derivatives in a one-pot procedure based on titanium-catalyzed MCR. The reactions are generally regioselective, and in some cases different regioisomeric products from the same reactants can be favored by choice of catalyst conditions.

Nitrogen heterocycles in general, and pyrroles in particular, are important frameworks in biology. Pyrrole rings are found in heme, chlorophyll and numerous natural products. Pyrroles are found in common dyes like BODIPY and many pharmaceuticals like atorvastatin (Lipitor) and sunitinib (Sutent).
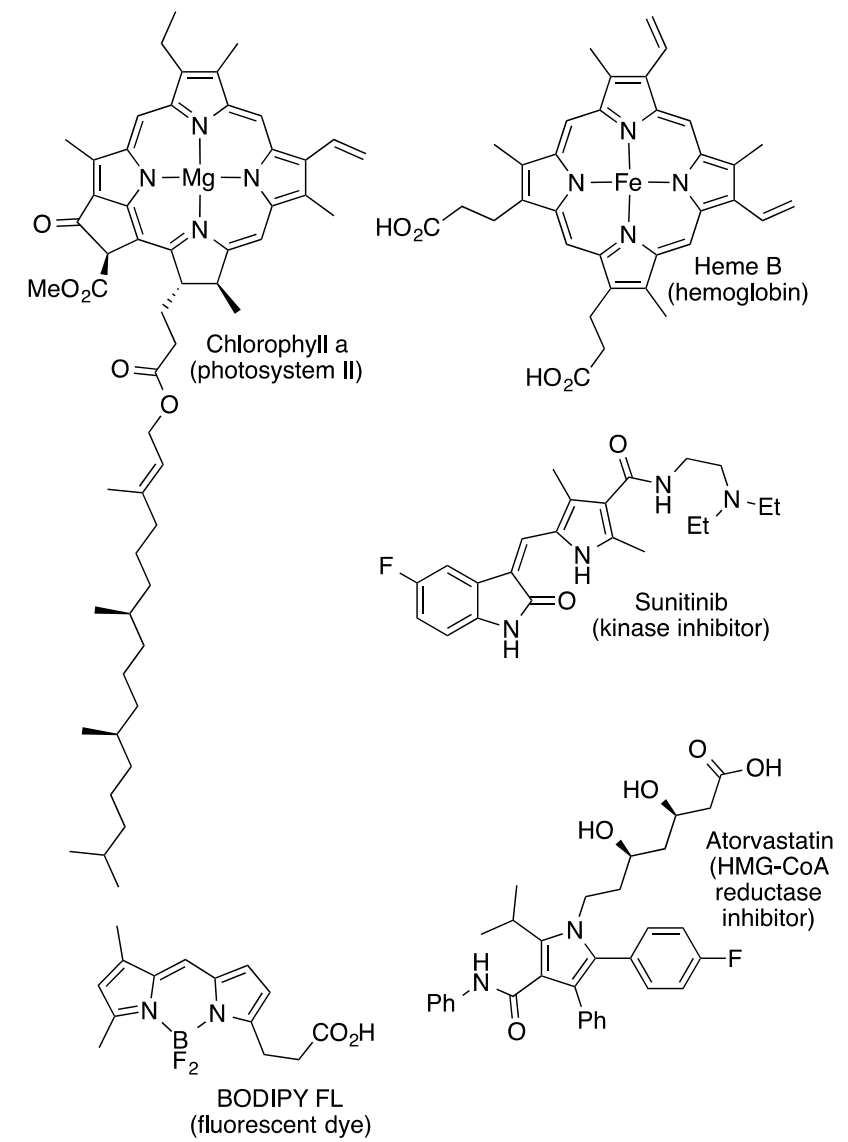

Chart 1. Pyrroles in biology, natural products, dyes, and pharmaceuticals.

As seen in the top two examples in Chart 1, pyrroles are commonly employed as ligands for metals, enabling a large variety of functions in biology. In fact, we also employ them as the ligands for our titanium catalysis to be discussed here (vide infra). ${ }^{3}$

Considering the importance of pyrroles, it is unsurprising that significant attention has been paid to their synthesis. Indeed, our group has published two quite different pyrrole syntheses based on titanium-catalysis previously. The first involved hydroamination of diynes to give iminoalkynes that cyclize to substituted pyrroles. The second synthesis involved a 4component coupling of alkyne, amine, and two equivalents of isonitrile to give unusual 2,3-diaminopyrroles catalyzed by a bis(indole)titanium complex.

There are several MCR methods for the synthesis of pyrroles, and the field has been recently reviewed. ${ }^{6}$ Notable among these are the traditional and modified Hantzsch syntheses involving, for example, phenacyl bromide, acetylacetone, and amines catalyzed by cyclodextrin (Scheme 1 top), which provides 2phenyl-3-keto-4-methylpyrroles with various substituents on the pyrrole nitrogen. ${ }^{7}$

The Paal-Knorr synthesis of pyrroles involves 1,4-diones and their reactions with amines (Scheme 1 middle) and is perhaps one of the best-known pyrrole syntheses. ${ }^{8}$
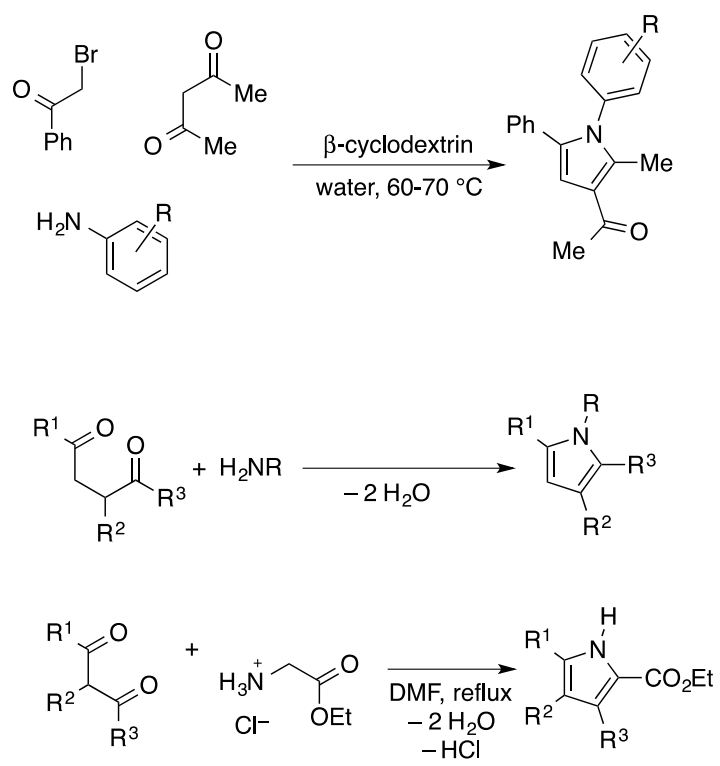

Scheme 1. Some "name reaction" examples of pyrrole syntheses. (top) Variant of the Hantzsch pyrrole synthesis. (middle) The Paal-Knorr synthesis of pyrroles. (bottom) The Mataka variant of the Fischer-Fink pyrrole synthesis using ethyl glycinate hydrochloride and 1,3-diones.

Another pyrrole synthesis of particular interest for placing this work in context is a variant of the Fischer-Fink reaction reported by Mataka and coworkers (Scheme 1 bottom). ${ }^{9}$ The reaction involves condensation of a 1,3-dione with ethyl glycinate in refluxing DMF. In the original publication, four 1,3-diones were used, which gave yields from 18-74\%.

What the reactions in Scheme 1 have in common is a reliance on 1,3- or 1,4-diones, a common trait of many pyrrole syntheses. One limitation on the variety of pyrroles accessible is the ease of synthesis of these diones. Here, we use titanium multicomponent coupling chemistry to generate 1,3-diimines, and we have developed one-pot conditions for their use in the Mataka variant of the Fischer-Fink reaction above. The methodology provides a host of pyrrole compounds from simple starting materials in a one-pot, 4-component sequence.

The general reaction sequence is shown in Scheme 2. The origins of the non-hydrogen atoms in the pyrrole ring, along with the bond disconnects, are also shown in the same scheme. The regioselectivity shown is for 2-carboxyl-4,5-disubstituted pyrroles, which are obtained for alkynes not bearing two aromatic substituents as will be discussed in detail below. 

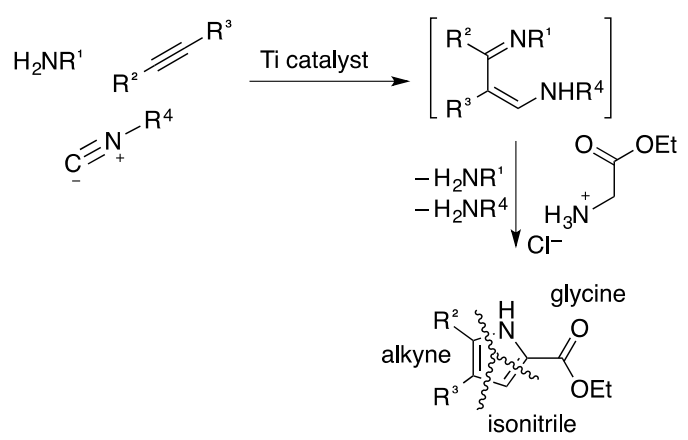

Scheme 2. General reaction sequence for the titaniumcatalyzed MCR reaction to generate pyrroles. The regioselectivity shown is for $\mathrm{R}^{2}$ or $\mathrm{R}^{3}=\mathrm{H}$ or alkyl (vide infra).

\section{Results and Discussion}

For this study, we used two different titanium catalysts. The ancillary ligands for the catalysts are pyrrole-based and are prepared in a single step. The first ligand type, $\mathrm{H}_{2} \mathrm{dpma}$, is prepared by 5-component coupling (a double Mannich reaction) between methylamine hydrochloride, 2 equiv. of formaline, and 2 equiv. of pyrrole. The second ligand type, $\mathrm{H}_{2} \mathrm{dpm}$, is prepared by condensation of pyrrole and acetone with catalytic trifluoroacetic acid. Both ligands are readily accessed on large scales and react with commercially available $\mathrm{Ti}\left(\mathrm{NMe}_{2}\right)_{4}$ to give catalysts $\mathbf{A}$ and $\mathbf{B}$ in near quantitative yields. ${ }^{10,11}$

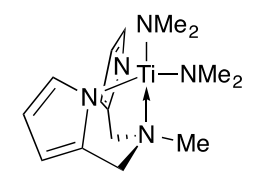

$\mathrm{Ti}(\mathrm{dpma})\left(\mathrm{NMe}_{2}\right)_{2}(\mathbf{A})$

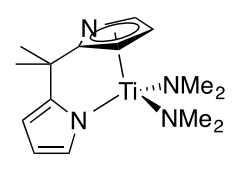

$\mathrm{Ti}(\mathrm{dpm})\left(\mathrm{NMe}_{2}\right)_{2}$ (B)
Chart 2. Structure of the titanium precatalysts used in this study.

The first advantage of using pyrrole-based ligands for this chemistry is the easily accessible multidentate ligands through simple condensation reactions described above. The second advantage is that relatively electron-deficient metal centers are obtained, which results in faster catalysis rates. ${ }^{12}$

The proposed mechanism for the titanium-catalyzed multicomponent coupling reaction is shown in Scheme 3. The two dimethylamido groups in the precatalyst are there to act as protolyzable leaving groups for a primary amine, a reaction that results in the formation of an imido $(\mathrm{Ti}=\mathrm{NR})$. The imido undergoes reversible $[2+2]$-cyclization with the alkyne to an azatitanacyclobutene (I). The Ti-C bond of the azatitanacyclobutene can be trapped by 1,1-insertion of the isonitrile to give metallacycle II. Protonolysis of the $\mathrm{Ti}-\mathrm{C}$ and $\mathrm{Ti}-\mathrm{N}$ bonds in the 5-membered metallacycle, shown stepwise through species III and IV, gives the product and regenerates the active catalyst. ${ }^{1}$

Catalyst $\mathbf{A}$ is a milder catalyst often used for terminal alkynes. Catalyst $\mathbf{B}$ is a more reactive species that is typically used for internal alkynes and bulkier substrates. There are regioselectivity differences in some cases with the two catalysts as well as will be explained.

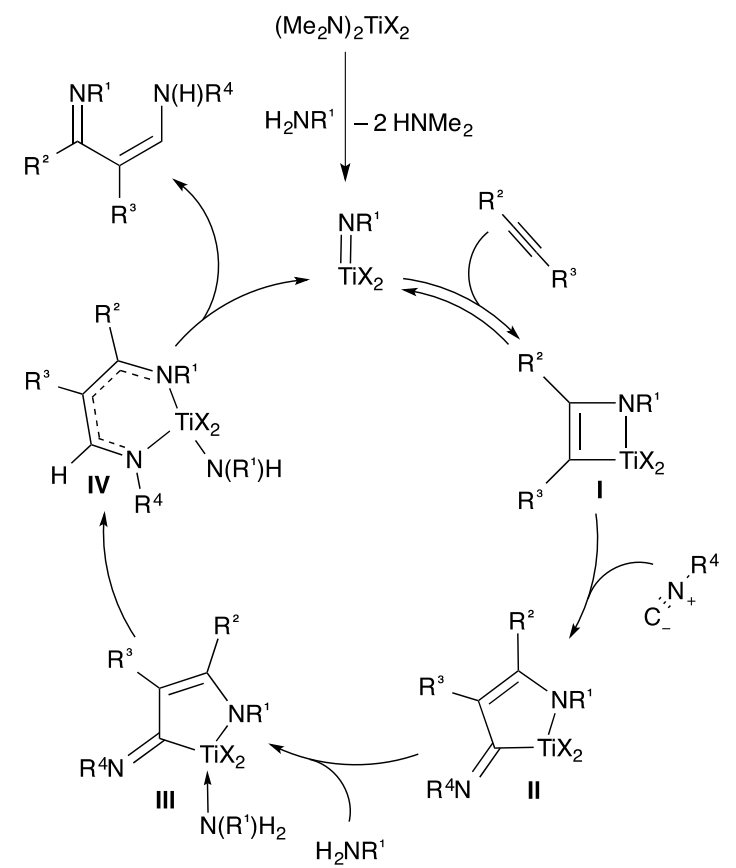

Scheme 3. Proposed mechanism for alkyne iminoamination to produce tautomers of 1,3-diimines.

In some cases, electronic effects in the alkyne substrates control the regioselectivities in the titanium-catalyzed MCR. This is the case for alkynes containing one $s p^{2}$-carbon, phenyl or vinyl, attached to the triple bond. For these substrates, there is a strong electronic preference for the $s p^{2}$-carbon substituent to be placed on the carbon between the two imines as shown in Eq 1 . The proposed cause for this is stabilization of the partial anionic charge on the carbon attached to titanium by $\mathrm{R}^{3}$ ( $\mathbf{I}$ in Scheme 3 ) when this group is, for example, phenyl. However, relative trapping rates of the two isomers will also contribute to the observed regioselectivity. ${ }^{1}$

If the alkyne is terminal with one alkyl group, such as 1hexyne, then the two catalysts in Chart 2 can be used to obtain either isomer as the major product of the reaction. This an apparent steric effect controlled by the two different catalyst structures of $\mathbf{A}$ and $\mathbf{B}$. The production of the major isomer can be further optimized by amine choice. For example, reaction of aniline, 1-hexyne, tert-butylisonitrile, and catalyst $\mathbf{A}$ results in a keto-aldimine 3CC product as the major isomer, as shown in Eq 2. Whereas, reaction of cyclohexylamine, 1-hexyne, tert-butyl isonitrile, and catalyst $\mathbf{B}$ results in a dialdimine $3 \mathrm{CC}$ product as the major isomer, as shown in Eq $3 .^{13}$

Initially, the cyclization of the iminoamination product with ethyl glycinate hydrochloride was optimized using an isolated model diimine, the product of 3-component coupling between phenylacetylene, cyclohexylamine, and tert-butylisonitrile catalyzed by A. It was discovered that use of DBU as a base was more reliable than several other bases, but triethylamine was acceptable for some substrates. Use of DMSO as the solvent also was found to be superior under the conditions examined over other solvents like DMF, toluene and EtOH. An excess of the ethyl glycinate hydrochloride improved yields, and the amount of base should be slightly lower than the equiv. of ethyl glycinate hydrochloride added. Typical conditions for the small-scale cyclization are shown in Eq 4. 
<smiles>[R]C#Cc1ccccc1</smiles>

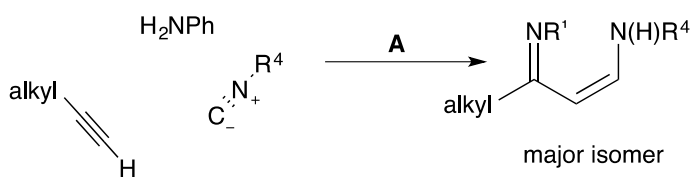

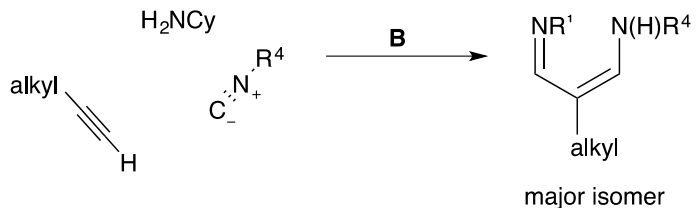

Alternatively, one can basify the ethyl glycinate hydrochloride with $\mathrm{K}_{2} \mathrm{CO}_{3}$ and use the ethyl glycinate with a catalytic amount of ammonium chloride, which is advisable for large-scale syntheses to avoid excessive use of DBU.

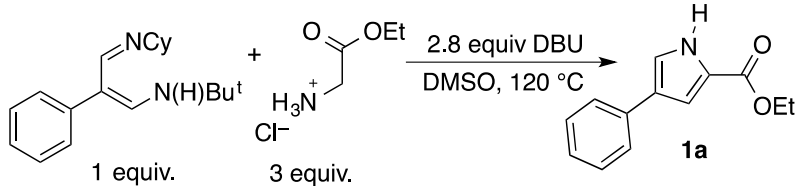

Yields from the ethyl glycinate hydrochloride/DBU and ethyl glycinate/catalytic acid procedures were comparable. For example, the one-pot synthesis of 1a (Eq. 5, Table 1) ethyl glycinate hydrochloride with DBU gave $50 \%$ isolated yield. Using ethyl glycinate with catalytic ammonium chloride gave $48 \%$ isolated yield on the same scale (Eq. 6). Pyrrole 1a was prepared on a $\sim 2 \mathrm{~g}$ scale using the procedure in Eq. 6 as well.<smiles>C#Cc1ccccc1Br</smiles>

(1) $10 \mathrm{~mol} \% \mathbf{A}$

toluene, $100^{\circ} \mathrm{C}$

(2) 3 equiv $\mathrm{H}_{2} \mathrm{NCH}_{2} \mathrm{CO}_{2} \mathrm{Et} \cdot \mathrm{HCl}$ 2.8 equiv. DBU, $120^{\circ} \mathrm{C}$, DMSO $50 \%$ isolated yield

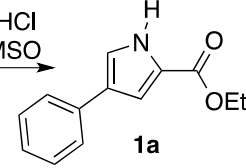<smiles>C#Cc1ccccc1</smiles>

(1) $10 \mathrm{~mol} \% \mathrm{~A}$,

toluene, $100{ }^{\circ} \mathrm{C}$

(2) 3 equiv $\mathrm{H}_{2} \mathrm{NCH}_{2} \mathrm{CO}_{2} \mathrm{Et}$ 0.4 equiv $\mathrm{NH}_{4} \mathrm{Cl}, 120{ }^{\circ} \mathrm{C}$, DMSO

$\mathrm{H}_{2} \mathrm{NCy}$ $48 \%$ isolated yield

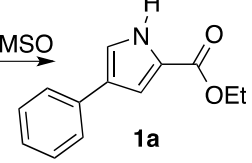

The results with terminal alkynes from the one-pot procedure with $1 \mathrm{mmol}$ of alkyne are provided in Table 1 . In all cases, the products are ethyl 2-carboxylpyrroles with the alkyne substituent in either the 4- or 5-position as determined by the titanium MCR. In aromatic- and vinyl-substituted alkynes only one isomer of the pyrrole generally was observed with a traces of the other isomer visible by GCMS in a few cases.

Catalyst structure can be used to control regiochemistry of the MCR product, ultimately affecting pyrrole selectivity. Alkynes 1hexyne and cyclohexylacetylene were subjected to 1,3-diimine formation conditions followed by one-pot pyrrole formation to form different regioisomers depending on initial catalyst choice. For example, use of 1-hexyne, aniline, tert-butylisonitrile and precatalyst $\mathbf{A}$ gives preferentially product $\mathbf{1 g}$ (i.e. ratio of $\mathbf{1 g}: \mathbf{1 h}$ is 6.4:1). Switching substrates from 1-hexyne to cyclohexylacetylene results in a decrease of 1,3-diimine product discrimination (i.e. ratio of $\mathbf{1 i}: \mathbf{1 j}$ is $3.4: 1$ ), but still favoring the 2carboxyl-5-alkylpyrrole. For all sets of conditions, the major isomer was easily separated by column chromatography.

Using precatalyst $\mathbf{B}$ with cyclohexylamine favors the production of 2-carboxyl-4-alkylpyrroles when using alkylsubstituted terminal alkynes. Production of cyclohexylacetylenederived $\mathbf{1 j}$ is favored 19:1, whereas production of 1-hexynederived $\mathbf{1 h}$ is favored by 12:1 using similar conditions (Scheme 4).

Table 1. Pyrroles derived from one-pot multicomponent couplings and cyclizations involving terminal alkynes.

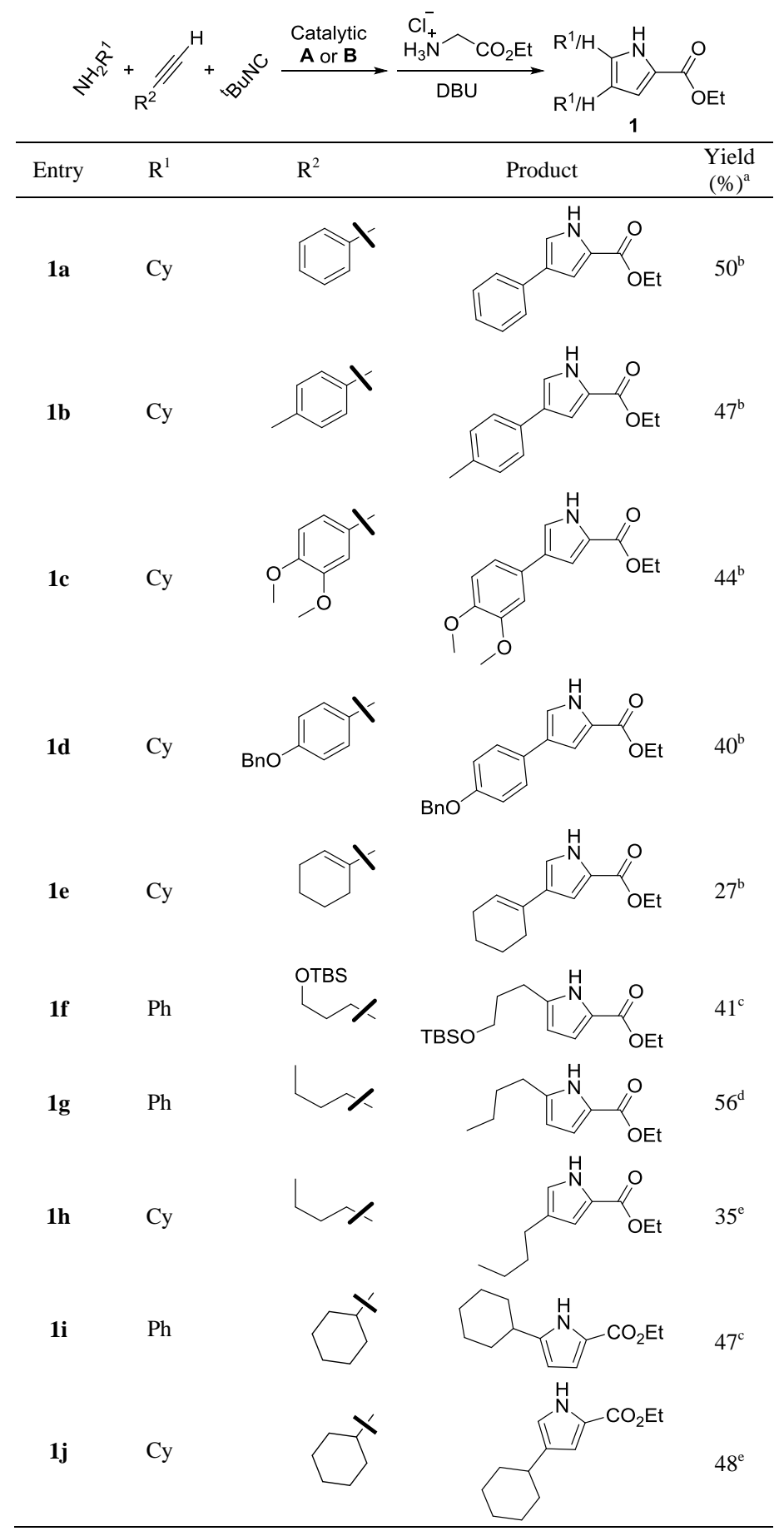

${ }^{a}$ Reaction conditions: Ti catalyst $(10 \mathrm{~mol} \%)$, toluene $(2 \mathrm{~mL})$, amine $(2 \mathrm{mmol})$, alkyne $(1 \mathrm{mmol})$, isonitrile $(1.2 \mathrm{mmol}), 100{ }^{\circ} \mathrm{C}, 24 \mathrm{~h}$; glycine ethyl ester hydrochloride (3 mmol), DBU $(2.8 \mathrm{mmol})$, and DMSO $(4 \mathrm{~mL}), 120^{\circ} \mathrm{C}, 18 \mathrm{~h}$. ${ }^{\mathrm{b}}$ Reaction carried out with cyclohexylamine and catalyst A. ${ }^{\mathrm{c}}$ Reaction carried out with aniline and catalyst A.. ${ }^{\mathrm{d}}$ Reaction carried out with aniline and 
catalyst $\mathbf{A}$ at $80{ }^{\circ} \mathrm{C}$. ${ }^{\mathrm{e}}$ Reaction carried out with cyclohexylamine and catalyst B.

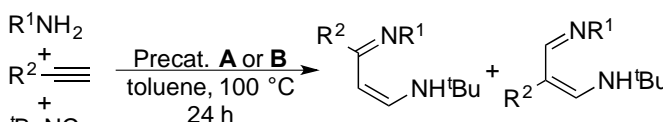

$$
\begin{aligned}
& \text { tBuñ } \\
& \mid \begin{array}{l}
{ }^{-} \\
\mathrm{Cl}_{3} \mathrm{~N} \\
\mathrm{DBU}, \mathrm{DMSO} \\
\mathrm{CO}_{2} \mathrm{Et} \\
120^{\circ} \mathrm{C}, 18 \mathrm{~h}
\end{array} \\
& \mathrm{R}^{2} \prod_{\mathrm{R}^{2}}^{\mathrm{H}} \mathrm{CO}_{2} \mathrm{Et}+\overbrace{}^{\mathrm{H}} \mathrm{CO}_{2} \mathrm{Et} \\
& \mathrm{R}^{1}=\mathrm{Ph}, \mathrm{R}^{2}={ }^{\mathrm{n} B u} \text {, Precat. A } 6.4: 1 \quad(\mathbf{g} / \mathbf{1 h}) \\
& \mathrm{R}^{1}=\mathrm{Cy}, \mathrm{R}^{2}={ }^{\mathrm{n}} \mathrm{Bu} \text {, Precat. B } 1: 12(\mathbf{1 g} / \mathbf{1 h}) \\
& \mathrm{R}^{1}=\mathrm{Ph}, \mathrm{R}^{2}=\mathrm{Cy} \text {, Precat. A } 3.4: 1 \quad(\mathbf{1 i} / \mathbf{1 j}) \\
& \mathrm{R}^{1}=\mathrm{Cy}, \mathrm{R}^{2}=\text { Cy, Precat. B } \quad 1: 19 \quad(\mathbf{1 i} / \mathbf{1 j})
\end{aligned}
$$

Scheme 4. The nature of the primary amine and precatalyst can be used to control the regioselectivity of the multicomponent coupling reaction and the pyrrole obtained as shown above using 1-hexyne and cyclohexylacetylene.

Table 2. Pyrroles derived from one-pot multicomponent couplings and cyclizations involving internal alkynes with isolated yields.

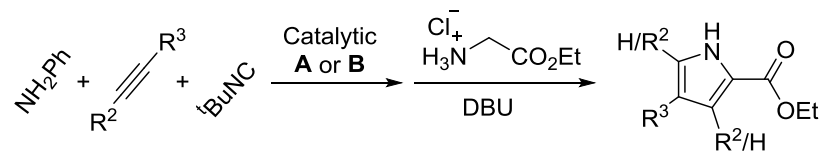

$$
\begin{aligned}
& 2
\end{aligned}
$$

Entry

${ }^{\mathrm{a}}$ Reaction conditions: Ti catalyst $\mathbf{B}(10 \mathrm{~mol} \%)$, toluene $(2 \mathrm{~mL})$, aniline ( 2 $\mathrm{mmol})$, alkyne $(1 \mathrm{mmol})$, isonitrile $(1.2) \mathrm{mmol}, 100{ }^{\circ} \mathrm{C}, 48 \mathrm{~h}$; glycine ethyl ester hydrochloride ( $3 \mathrm{mmol}), \mathrm{DBU}(2.8 \mathrm{mmol})$, and DMSO $(4 \mathrm{~mL}), 120^{\circ} \mathrm{C}$, $18 \mathrm{~h}$. ${ }^{\mathrm{b}}$ Regioisomer isolated determined by HSQC. ${ }^{\mathrm{c}}$ Regioisomer isolated determined by single crystal X-ray diffraction.

In the majority of the cases in Table 1 , there are no possible regiochemical issues associated with the addition of the ethyl glycinate to the iminoamination product (Scheme 4). In entry $\mathbf{1 g}$ and $\mathbf{1 i}$ in Table 1 and all the examples in Table 2, one can anticipate two possible products from the reaction of ethyl glycinate with the 1,3-diimine: one product due to addition of the glycine nitrogen to the ketimine side and one product due to addition of nitrogen to the aldimine side.

We can explain the regiochemical results for glycine addition to the MCR product using a simple model based on the assumption that the regiochemistry is determined by an irreversible $\mathrm{C}-\mathrm{C}$ bond formation during the initial ring closure. Fast equilibria prior to this irreversible step are assumed to have little affect on the regiochemical outcome and exchange of amines in the 1,3-diimine 3-component coupling products are considered fast. As a result, the glycine can be considered to be in fast equilibrium between the two possible positions of the 1,3diimine (Figure 1).

If $\mathrm{R}^{2}=$ alkyl, then the favored ring closure is due to nucleophilic attack on the aldimine carbon (Figure 1, top), which gives the major isomer as the 2- $\mathrm{CO}_{2} \mathrm{Et}-4,5$-disubstituted pyrrole. If $\mathrm{R}^{2}=$ aryl, one can postulate that the aromatic group encourages nucleophilic attack on the ketimine carbon, which results in a 2$\mathrm{CO}_{2}$ Et-3,4-disubstituted pyrrole product (Figure 1, bottom).
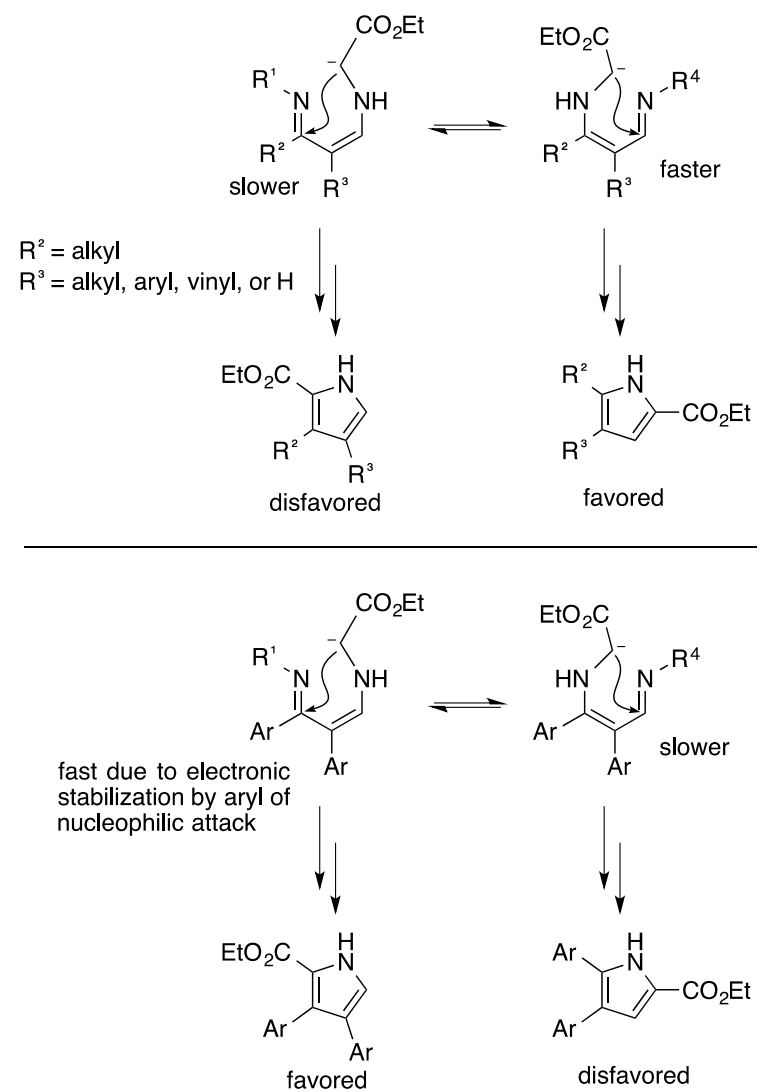

Figure 1. Model for the regiochemistry from the pyrrole synthesis using glycine and the iminoamination products.

To investigate the plausibility of these assertions, two reactions were followed by ${ }^{1} \mathrm{H}$ NMR, GC/MS, and GC/FID. In these reactions of the MCR product, glycine ethyl ester and catalytic ammonium chloride were added (Method B). The MCR products employed were $\mathbf{3 a}$ and $\mathbf{3 b}$ shown below as their diimine tautomers, which can be used to prepare pyrroles $\mathbf{2 a}$ and $\mathbf{2 b}$. The reactions were done at a relatively low temperature, $55^{\circ} \mathrm{C}$, to observe transimination with little to no pyrrole formation. Interestingly, the only new free amine observed during the reaction at low pyrrole formation $(<30 \%)$ was aniline. This could imply the substitution is only occurring at the ketimine site; however, it should be noted that Stefano and coworkers have 
found that aliphatic amines will preferentially displace aromatic amines from imines. ${ }^{14}$ As a result, any tert-butylamine liberated by reaction with excess glycine may be reacting further to displace aniline. Consequently, observation of no free tertbutylamine in the reaction does not necessarily imply that no exchange is occurring with the aldimine site. In fact, there are new compounds observed in the GC/MS with the appropriate mass to be these di-tert-butylimines. ${ }^{15}$<smiles></smiles>

3a<smiles>CC(C)(C)C(=N)C(c1ccccc1)c1ccccc1</smiles>

3b
In the case of reaction of $\mathbf{3 a}$ with glycine, no pyrrole formation is observed at $55^{\circ} \mathrm{C}$ for $14 \mathrm{~h}$; however, some pyrrole is formed ( $11 \%$ yield) in the reaction $\mathbf{3 b}$, under the same conditions with faster ring closure to product in this case due to the phenylgroup on the ketimine carbon. In other words, all the data collected were consistent with the model in Figure 1 where the transimination site has little effect on the isomer and the phenyl group on the imine carbon in $\mathbf{3 b}$ speeds ring-closure. It is proposed that the relative rate of ring closure on the ketimine and aldimine sites is the major factor in determining regioselectivity. ${ }^{16,17}$ This model also explains Mataka and coworkers' regioselectivity results with 1,3-diketones. ${ }^{9}$

\section{Concluding Remarks}

The ethyl ester of glycine adds smoothly to the products of titanium-catalyzed iminoamination, 1,3-diimines, to give $\mathrm{NH}$ pyrroles. The control of regioselectivity in the iminoamination reaction allows selective placement of aromatic and other $s p^{2}$ hybridized carbons in the 4-position of the pyrrole product, and all alkynes bearing one of these groups shows this selectivity. Further, if the alkyne bears one alkyl substituent, e.g., the butylgroup of 1-hexyne, this group can be placed in either the 4- or 5position with good selectivity depending on catalyst and conditions chosen.

From the standpoint of the alkyne starting material for the two-step sequence, one can briefly describe the accessible pyrrole products as shown in Figure 2, where $\mathrm{R}=$ alkyl and $\mathrm{C}\left(\mathrm{sp}^{2}\right)=$ aryl or vinyl.
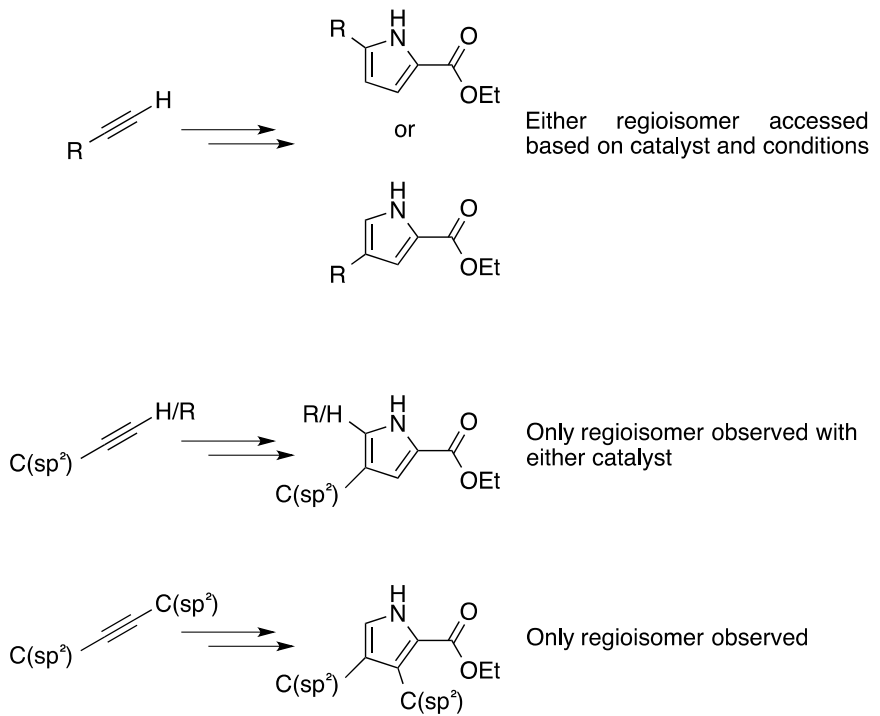

Figure 2. From the standpoint of the starting alkyne, the pyrroles shown can be accessed based on the alkynes substituents using the chemistry described here. $\mathrm{R}=$ alkyl, $\mathrm{C}\left(\mathrm{sp}^{2}\right)=$ aryl or vinyl
The isolated yields of the reactions are from $25-65 \%$ for this 2-step, one-pot multicomponent coupling route. This chemistry allows for very rapid access to a large number of different pyrroles for study, and we believe the chemistry will afford efficient production of more complex pyrrole derivatives.

\section{Experimental Section}

\subsection{General Considerations}

All manipulations of air-sensitive compounds were carried out in an MBraun drybox under a purified nitrogen atmosphere. All glassware was heated at $150{ }^{\circ} \mathrm{C}$ for $4 \mathrm{~h}$ and stored in a drybox under nitrogen. Toluene was purified by first sparging with dry nitrogen to remove oxygen and then run through activated alumina to remove water. ${ }^{1} \mathrm{H}$ and ${ }^{13} \mathrm{C}$ NMR spectra were recorded on a VXR-500 spectrometer in $\mathrm{CDCl}_{3}$. Regiochemistry of compounds $\mathbf{2 a - 2 f}, \mathbf{3 b}$ and $\mathbf{3 c}$ were determined by coupled-HSQC (see the Supporting Information). Melting points were measured on a Mel-Temp II apparatus (Laboratory Devices Inc, USA) with a mercury thermometer in an open capillary tube. Single crystal X-ray diffraction data was collected in the Center for Crystallographic Research at MSU. Ligands $\mathrm{H}_{2} \mathrm{dpma}^{18}$ and $\mathrm{H}_{2} \mathrm{dpm}^{19}$ were prepared by literature methods. $\mathrm{Ti}\left(\mathrm{NMe}_{2}\right)_{2}(\mathrm{dpma})$ $(\mathbf{A})^{10}$ and $\mathrm{Ti}\left(\mathrm{NMe}_{2}\right)_{2}(\mathrm{dpm})(\mathbf{B})^{11}$ were made following literature procedures. Alkynes were purchased either from Sigma-Aldrich or GFS chemicals then distilled from $\mathrm{CaO}$ under dry nitrogen or prepared using Sonogashira coupling. ${ }^{20}$ Amines were purchased from Sigma-Aldrich and were distilled from $\mathrm{KOH}$ under dry nitrogen. Triethylamine (TEA), glycine ethyl ester hydrochloride, and sarcosine ethyl ester hydrochloride were all purchased from Sigma-Aldrich and used as received. tert-Butylisonitrile was prepared from tert-butylamine, $\mathrm{CHCl}_{3}$, and aqueous base according to the literature procedure and purified by distillation under dry nitrogen. ${ }^{21}$ tert-Butyldimethylsilyl chloride and 1,8diazabicyclo[5.4.0] undec-7-ene (DBU) were purchased from Oakwood Chemicals and used as received. Dimethylsulfoxide (DMSO) was purchased from Fisher Scientific and used as received. Hexanes and ethyl acetate were purchased from Mallinckrodt Chemicals and used as received.

Ethyl glycinate was basified for Methods B and C below by dissolving ethyl glycinate hydrochloride in water and adding 2 equiv of $\mathrm{K}_{2} \mathrm{CO}_{3}$. The solution was extracted with dichloromethane in three portions. The combined organic layers were dried and filtered; then, the volatiles were removed by rotary evaporation to give the ethyl glycinate as a clear to pale yellow oil.

\subsection{General procedure for 1,3-diimine Synthesis}

A pressure tube was charged with a magnetic stir bar and $\mathrm{Ti}$ precatalyst A or B (10 mol\%) in toluene $(2 \mathrm{~mL})$, amine $(2 \mathrm{mmol})$, alkyne $(1 \mathrm{mmol})$, and t-butylisonitrile $(1.2 \mathrm{mmol})$ were added. The pressure tube was sealed, removed from the drybox, and placed into an oil bath preheated to $100-120{ }^{\circ} \mathrm{C}$ for $24-48 \mathrm{~h}$. The reaction was removed from the bath, and volatiles were removed in vacuo.

\subsection{General procedures for 2-carboxylpyrroles}

\subsubsection{Method A}

The pressure tube from 1,3-diimine formation was charged with glycine ethyl ester hydrochloride ( $420 \mathrm{mg}, 3 \mathrm{mmol})$, DBU $(420 \mu \mathrm{L}, 2.8 \mathrm{mmol})$, and DMSO $(4 \mathrm{~mL})$. The pressure tube was resealed and heated for $18 \mathrm{~h}$ at $120^{\circ} \mathrm{C}$ in an oil bath. The reaction was removed from the bath and extracted with DCM $(40 \mathrm{~mL})$. The organic layer was washed with $10 \% \mathrm{NaHCO}_{3}(30 \mathrm{~mL})$ and with brine $(30 \mathrm{~mL})$. The aqueous layers were combined and 
washed with DCM (40 mL). The organic layers were combined, dried with anhydrous $\mathrm{Na}_{2} \mathrm{SO}_{4}$, and filtered. Volatiles were removed, and the crude was purified by flash column chromatography on silica gel with hexanes:ethyl acetate (4:1) and $1 \%$ TEA to afford the desired product.

\subsubsection{Method B}

The pressure tube from 1,3-diimine formation was charged with glycine ethyl ester ( $309 \mathrm{mg}, 3 \mathrm{mmol}), \mathrm{NH}_{4} \mathrm{Cl}(22 \mathrm{mg}, 0.4$ $\mathrm{mmol})$, and DMSO (4 mL). The pressure tube was resealed and heated for $18 \mathrm{~h}$ at $120{ }^{\circ} \mathrm{C}$ in an oil bath. The reaction was removed from the bath, and extracted with DCM $(40 \mathrm{~mL})$. The organic layer was washed with $10 \% \mathrm{NaHCO}_{3}(30 \mathrm{~mL})$ and with brine $(30 \mathrm{~mL})$. The aqueous layers were combined and washed with DCM $(40 \mathrm{~mL})$. The organic layers were combined, dried with anhydrous $\mathrm{Na}_{2} \mathrm{SO}_{4}$, and filtered. Volatiles were removed, and the crude was purified by flash column chromatography on silica gel with hexanes:ethyl acetate (4:1) and 1\% TEA to afford desired product.

\subsubsection{Method C}

All materials from method B were scaled to alkyne (20 mmol).

\subsection{Preparative details}

\subsubsection{Synthesis of ethyl 4-phenyl-pyrrole-2- carboxylate (1a)}

1,3-diimine synthesis followed general procedure using $\mathrm{Ti}$ precatalyst A (32.4 mg, $10 \mathrm{~mol} \%)$, cyclohexylamine $(230 \mu \mathrm{L}, 2$ mmol), phenylacetylene $(110 \mu \mathrm{L}, 1 \mathrm{mmol})$ and heating at $100{ }^{\circ} \mathrm{C}$ for $24 \mathrm{~h}$. Method A: The pyrrole was afforded (108 $\mathrm{mg}, 50 \%)$ as a light brown solid. Method B: The pyrrole was afforded (104 $\mathrm{mg}, 48 \%$ ) as a light brown solid. Method C: The pyrrole was afforded $(1.8 \mathrm{~g}, 42 \%)$ as a light brown solid. M.p. $97-99{ }^{\circ} \mathrm{C}$ (lit. ${ }^{20}$ Mp: 98-99 $\left.{ }^{\circ} \mathrm{C}\right) . \mathrm{R}_{f}\left(25 \%\right.$ EtOAc/hexane) $0.18 .{ }^{1} \mathrm{H} \mathrm{NMR}\left(\mathrm{CDCl}_{3}\right)$ : $\delta 9.25(1 \mathrm{H}$, br s, N-H pyrrole), 7.44-7.46 (2H, m, Ar-H), 7.27$7.30(2 \mathrm{H}, \mathrm{m}, \mathrm{Ar}-\mathrm{H}), 7.14-7.18(3 \mathrm{H}, \mathrm{m}, \mathrm{Ar}-\mathrm{H}$ and $\mathrm{C}-\mathrm{H}$ pyrrole), $4.28\left(2 \mathrm{H}, \mathrm{q}, \mathrm{J}_{\mathrm{HH}}=7.2 \mathrm{~Hz}, \mathrm{CH} 2\right), 1.31\left(3 \mathrm{H}, \mathrm{t}, \mathrm{J}_{\mathrm{HH}}=7.2 \mathrm{~Hz}, \mathrm{CH} 3\right)$. ${ }^{13} \mathrm{C}\left\{{ }^{1} \mathrm{H}\right\}$ NMR $\left(\mathrm{CDCl}_{3}\right): \delta 161.2,134.5,128.7,126.5,125.3$, $123.7,119.4,112.4,60.5,14.4$. Elemental analysis: found $\% \mathrm{C}$ $72.45, \% \mathrm{H}$ 6.46, \% N 6.59; calcd.; \%C 72.54, \% $6.09, \% \mathrm{~N} 6.51$.

\subsubsection{Synthesis of ethyl 4-(p-tolyl)-pyrrole-2- carboxylate (1b)}

1,3-diimine synthesis followed general procedure using $\mathrm{Ti}$ precatalyst A (32.4 mg, $10 \mathrm{~mol} \%)$, cyclohexylamine $(230 \mu \mathrm{L}, 2$ mmol), 1-ethynyl-4-methylbenzene (127 $\mu \mathrm{L}, 1 \mathrm{mmol})$ and heating at $100{ }^{\circ} \mathrm{C}$ for $24 \mathrm{~h}$. Method A: The pyrrole was afforded $(108 \mathrm{mg}, 47 \%)$ as a light orange solid. M.p. 166-167 ${ }^{\circ} \mathrm{C}$ (lit. ${ }^{20}$ Mp: $\left.165-166{ }^{\circ} \mathrm{C}\right) . \quad \mathrm{R}_{f}\left(25 \%\right.$ EtOAc/hexane) $0.19 .{ }^{1} \mathrm{H}$ NMR $\left(\mathrm{CDCl}_{3}\right) \delta 9.27\left(1 \mathrm{H}\right.$, br s, N-H pyrrole), $7.43\left(2 \mathrm{H}, \mathrm{d}, \mathrm{J}_{\mathrm{HH}}=3.1\right.$ $\mathrm{Hz}, \mathrm{Ar}-\mathrm{H}), 7.18-7.22$ (m, 4H, Ar-H and C-H pyrrole), $4.36(2 \mathrm{H}$, $\left.\mathrm{q}, \mathrm{J}_{\mathrm{HH}}=7.2 \mathrm{~Hz}, \mathrm{CH} 2\right), 1.40\left(3 \mathrm{H}, \mathrm{t}, \mathrm{J}_{\mathrm{HH}}=7.2 \mathrm{~Hz}, \mathrm{CH} 3\right) ;{ }^{13} \mathrm{C}\left\{{ }^{1} \mathrm{H}\right\}$ $\operatorname{NMR}\left(\mathrm{CDCl}_{3}\right) \delta 161.2,135.9,131.7,129.5,126.8,125.2,123.6$, $119.1,112.3,60.5,21.1,14.5$; elemental analysis: found $\% \mathrm{C}$ $73.42, \% \mathrm{H}$ 6.49, \%N 6.19; calcd. \%C 73.34, \% $6.59, \% \mathrm{~N} 6.11$.

\subsubsection{Synthesis of ethyl 4-(3,4-dimethoxy)phenyl- pyrrole-2-carboxylate (1c)}

1,3-diimine synthesis followed general procedure using $\mathrm{Ti}$ precatalyst A (32.4 mg, $10 \mathrm{~mol} \%)$, cyclohexylamine $(230 \mu \mathrm{L}, 2$ mmol), 1-ethynyl-3,4-dimethoxybenzene (162 mg, $1 \mathrm{mmol})$ and heating at $100{ }^{\circ} \mathrm{C}$ for $24 \mathrm{~h}$. Method A: The pyrrole was afforded $(121 \mathrm{mg}, 44 \%)$ as a light yellow solid. M.p. 141-142 ${ }^{\circ} \mathrm{C}$ (lit. ${ }^{22}$ Mp: $\left.136.3-137.5{ }^{\circ} \mathrm{C}\right) . \mathrm{R}_{f}\left(25 \%\right.$ EtOAc/hexane) $0.06 .{ }^{1} \mathrm{H}$ NMR $\left(\mathrm{CDCl}_{3}\right) \delta 9.18(1 \mathrm{H}$, br s, N-H pyrrole $), 7.15-7.18(2 \mathrm{H}, \mathrm{m}, \mathrm{C}-\mathrm{H}$ pyrrole), $7.08\left(1 \mathrm{H}, \mathrm{dd}, \mathrm{J}_{\mathrm{HH}}=8.4 \mathrm{~Hz}, 2.1 \mathrm{~Hz}, \mathrm{Ar}-\mathrm{H}\right), 7.04(1 \mathrm{H}, \mathrm{d}$,
$\left.\mathrm{J}_{\mathrm{HH}}=2.1 \mathrm{~Hz}, \mathrm{Ar}-\mathrm{H}\right), 6.89\left(1 \mathrm{H}, \mathrm{d}, \mathrm{J}_{\mathrm{HH}}=8.4 \mathrm{~Hz}\right.$, Ar- $\left.\mathrm{H}\right), 4.36$ $\left(2 \mathrm{H}, \mathrm{q}, \mathrm{J}_{\mathrm{HH}}=7.2 \mathrm{~Hz}, \mathrm{CH}_{2}\right), 3.94\left(3 \mathrm{H}, \mathrm{s}, \mathrm{CH}_{3}\right), 3.90\left(3 \mathrm{H}, \mathrm{s}, \mathrm{CH}_{3}\right)$, $1.39\left(3 \mathrm{H}, \mathrm{t}, \mathrm{J}_{\mathrm{HH}}=7.2 \mathrm{~Hz}, \mathrm{CH}_{3}\right) .{ }^{13} \mathrm{C}\left\{{ }^{1} \mathrm{H}\right\} \mathrm{NMR}\left(\mathrm{CDCl}_{3}\right) \delta 161.1$, $149.2147 .8,127.7,126.8,123.6,118.8,117.6,112.2,111.6$, $108.9,60.5,56.0,59.9$, 14.5. HRMS (ES) $\mathrm{m} / \mathrm{z}$ calcd. for $\mathrm{C}_{15} \mathrm{H}_{16} \mathrm{NO}_{4}$ 274.1079, found 274.1089.

\subsubsection{Synthesis of ethyl 4-(4-benzyloxy)phenyl- pyrrole-2-carboxylate (1d)}

1,3-diimine synthesis followed general procedure using $\mathrm{Ti}$ precatalyst A $(32.4 \mathrm{mg}, 10 \mathrm{~mol} \%)$, cyclohexylamine $(230 \mu \mathrm{L}, 2$ mmol), 1-ethynyl-4-benzyloxybenzene (208 mg, $1 \mathrm{mmol})$ and heating at $100{ }^{\circ} \mathrm{C}$ for $24 \mathrm{~h}$. Method A: The pyrrole was afforded (128 mg, 40\%) as a red solid. M.p. $146-147{ }^{\circ} \mathrm{C} . \mathrm{R}_{f}(25 \%$ EtOAc/hexane) $0.15 .{ }^{1} \mathrm{H}$ NMR $\left(\mathrm{CDCl}_{3}\right) \delta 9.22(1 \mathrm{H}$, br s, N-H pyrrole), 7.29-7.44 (7H, m, Ar-H), 7.12-7.13 (2H, m, Ar-H and $\mathrm{C}-\mathrm{H}$ pyrrole), 6.92-6.98 (2H, m, Ar-H and $\mathrm{C}-\mathrm{H}$ pyrrole), 5.06 $\left(2 \mathrm{H}, \mathrm{s}, \mathrm{CH}_{2}\right), 4.33\left(2 \mathrm{H}, \mathrm{q}, \mathrm{J}_{\mathrm{HH}}=7.1 \mathrm{~Hz}, \mathrm{CH}_{2}\right), 1.37\left(3 \mathrm{H}, \mathrm{t}, \mathrm{J}_{\mathrm{HH}}=\right.$ $\left.7.1 \mathrm{~Hz}, \mathrm{CH}_{3}\right) .{ }^{13} \mathrm{C}\left\{{ }^{1} \mathrm{H}\right\}$ NMR $\left(\mathrm{CDCl}_{3}\right) \delta 161.2,157.5,137.1$, $128.5,127.9,127.6,127.4,126.5,126.4,123.5,118.7,115.2$, $112.1,70.1,60.3,14.4$. Elemental analysis: found $\% \mathrm{C} 74.64, \% \mathrm{H}$ $5.89, \% \mathrm{~N} 4.42$; calcd. \%C 74.75, \% H 5.96, \% 4.36 .

\subsubsection{Synthesis of ethyl 4-(cyclohexen-1-yl)- pyrrole-2-carboxylate (1e)}

1,3-diimine synthesis followed general procedure using $\mathrm{Ti}$ precatalyst A (32.4 mg, $10 \mathrm{~mol} \%)$, cyclohexylamine $(230 \mu \mathrm{L}, 2$ mmol), 1-cyclohexenylacetylene $(123 \mu \mathrm{L}, 1 \mathrm{mmol})$ and heating at $100{ }^{\circ} \mathrm{C}$ for $24 \mathrm{~h}$. Method A: The pyrrole was afforded (59 mg, $27 \%)$ as a brown solid. M.p. $56-59{ }^{\circ} \mathrm{C} . \mathrm{R}_{f}(25 \%$ EtOAc/hexane) 0.21. ${ }^{1} \mathrm{H}$ NMR $\left(\mathrm{CDCl}_{3}\right) \delta 9.28(1 \mathrm{H}$, br s, N-H pyrrole $), 6.95(1 \mathrm{H}$, $\mathrm{d}, \mathrm{J}_{\mathrm{HH}}=1.7 \mathrm{~Hz}, \mathrm{C}-\mathrm{H}$ pyrrole $), 6.88\left(1 \mathrm{H}, \mathrm{d}, \mathrm{J}_{\mathrm{HH}}=1.7 \mathrm{~Hz}, \mathrm{C}-\mathrm{H}\right.$ pyrrole), 5.98-6.00 $(1 \mathrm{H}, \mathrm{m}, \mathrm{C}-\mathrm{H}$ alkene $), 4.28\left(2 \mathrm{H}, \mathrm{q}, \mathrm{J}_{\mathrm{HH}}=7.2\right.$ $\left.\mathrm{Hz}, \mathrm{CH}_{2}\right), 2.24-2.27\left(2 \mathrm{H}, \mathrm{m}, \mathrm{CH}_{2}\right), 2.10-2.14\left(2 \mathrm{H}, \mathrm{m}, \mathrm{CH}_{2}\right), 1.68-$ $1.73\left(2 \mathrm{H}, \mathrm{m}, \mathrm{CH}_{2}\right), 1.58-1.63\left(2 \mathrm{H}, \mathrm{m}, \mathrm{CH}_{2}\right), 1.31-1.39\left(3 \mathrm{H}, \mathrm{t}, \mathrm{J}_{\mathrm{HH}}\right.$ $\left.=7.2 \mathrm{~Hz}, \mathrm{CH}_{3}\right) .{ }^{13} \mathrm{C}\left\{{ }^{1} \mathrm{H}\right\} \mathrm{NMR}\left(\mathrm{CDCl}_{3}\right) \delta 161.4,129.9,122.8$, 120.6, 118.4, 110.9, 60.3, 27.0, 25.3, 22.7, 22.3, 14.4. Elemental

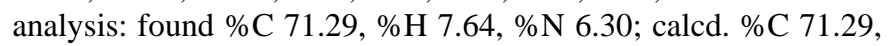
$\% \mathrm{H} 7.81, \% \mathrm{~N} 6.39$.

\subsubsection{Synthesis of ethyl 5-(3- tertbutyldimethylsilyloxy)propyl-pyrrole-2- carboxylate $(\mathbf{1 f})$}

1,3-diimine synthesis followed general procedure using $\mathrm{Ti}$ precatalyst A (32.4 mg, $10 \mathrm{~mol} \%)$, cyclohexylamine $(230 \mu \mathrm{L}, 2$ mmol), 1-t-butyldimethylsilyloxy-pent-4-yne (236 $\mu \mathrm{L}, 1 \mathrm{mmol})$ and heating at $100{ }^{\circ} \mathrm{C}$ for $24 \mathrm{~h}$. Method A: The pyrrole was afforded $(128 \mathrm{mg}, 41 \%)$ as a light brown solid. M.p. $63-64{ }^{\circ} \mathrm{C} . \mathrm{R}_{f}$ (25\% EtOAc/hexane) 0.51. ${ }^{1} \mathrm{H} \mathrm{NMR}\left(\mathrm{CDCl}_{3}\right): \delta 9.31(1 \mathrm{H}, \mathrm{br} \mathrm{s}$, $\mathrm{N}-\mathrm{H}$ pyrrole), $6.81\left(1 \mathrm{H}, \mathrm{d}, \mathrm{J}_{\mathrm{HH}}=3.3 \mathrm{~Hz}, \mathrm{C}-\mathrm{H}\right.$ pyrrole $), 5.94(1 \mathrm{H}$, $\mathrm{d}, \mathrm{J}_{\mathrm{HH}}=3.3 \mathrm{~Hz}, \mathrm{C}-\mathrm{H}$ pyrrole $), 4.27\left(2 \mathrm{H}, \mathrm{q}, \mathrm{J}_{\mathrm{HH}}=7.2 \mathrm{~Hz}, \mathrm{CH}_{2}\right)$, $3.62\left(2 \mathrm{H}, \mathrm{t}, \mathrm{J}_{\mathrm{HH}}=5.9 \mathrm{~Hz}, \mathrm{CH}_{2}\right), 2.69\left(2 \mathrm{H}, \mathrm{t}, \mathrm{J}_{\mathrm{HH}}=7.3 \mathrm{~Hz}, \mathrm{CH}_{2}\right)$ $1.79-1.85\left(2 \mathrm{H}\right.$, quin, $\left.\mathrm{J}_{\mathrm{HH}}=7.3 \mathrm{~Hz}, 6.7 \mathrm{~Hz}, \mathrm{CH}_{2}\right), 1.31-1.40(3 \mathrm{H}, \mathrm{t}$, $\left.\mathrm{J}_{\mathrm{HH}}=7.2 \mathrm{~Hz}, \mathrm{CH}_{3}\right), 0.89(9 \mathrm{H}, \mathrm{s}), \delta 0.03\left(6 \mathrm{H}, \mathrm{s}, \mathrm{CH}_{3}-\mathrm{Si}\right) .{ }^{13} \mathrm{C}\left\{{ }^{1} \mathrm{H}\right\}$ NMR $\left(\mathrm{CDCl}_{3}\right): \delta 161.2,138.1,121.3,115.8,108.0,61.9,59.9$, $31.9,25.9,24.1,18.3,14.5,-5.3$. Elemental analysis: found $\% \mathrm{C}$ 61.82, \%H 9.13, \%N 4.78; calcd. \%C 61.69, \%H 9.38, \% 4.50.

\subsubsection{Synthesis of ethyl 5-butyl-pyrrole-2- carboxylate $(\mathbf{1 g})$}

1,3-diimine synthesis followed general procedure using $\mathrm{Ti}$ precatalyst $\mathbf{A}(32.4 \mathrm{mg}, 10 \mathrm{~mol} \%)$, aniline $(180 \mu \mathrm{L}, 2 \mathrm{mmol}), 1-$ hexyne $(115 \mu \mathrm{L}, 1 \mathrm{mmol})$ and heating at $100{ }^{\circ} \mathrm{C}$ for $24 \mathrm{~h}$. Method A: The pyrrole was formed after heating at $80{ }^{\circ} \mathrm{C}$ for $18 \mathrm{~h}$ and afforded (109 $\mathrm{mg}, 56 \%)$ as a brown oil. $\mathrm{R}_{f}(25 \% \mathrm{EtOAc} /$ hexane) 0.49. ${ }^{1} \mathrm{H} \mathrm{NMR}\left(\mathrm{CDCl}_{3}\right): \delta 9.40(1 \mathrm{H}$, br s, N-H pyrrole $), 6.80(1 \mathrm{H}$, $\mathrm{d}, \mathrm{J}_{\mathrm{HH}}=2.6 \mathrm{~Hz}, \mathrm{C}-\mathrm{H}$ pyrrole $), 5.94\left(1 \mathrm{H}, \mathrm{d}, \mathrm{J}_{\mathrm{HH}}=2.6 \mathrm{~Hz}, \mathrm{CH}-\right.$ 
pyrrole), $4.28\left(2 \mathrm{H}, \mathrm{q}, \mathrm{J}_{\mathrm{HH}}=7.2 \mathrm{~Hz}, \mathrm{CH}_{2}\right), 2.61\left(2 \mathrm{H}, \mathrm{t}, \mathrm{J}_{\mathrm{HH}}=7.5\right.$ $\left.\mathrm{Hz}, \mathrm{CH}_{2}\right), 1.57-1.63\left(2 \mathrm{H}\right.$, quin, $\left.\mathrm{J}_{\mathrm{HH}}=7.5 \mathrm{~Hz}, 7.0 \mathrm{~Hz}, \mathrm{CH}_{2}\right), 1.31-$ $1.35\left(5 \mathrm{H}, \mathrm{m}, \mathrm{CH}_{2}\right.$ and $\left.\mathrm{CH}_{3}\right), 0.89\left(3 \mathrm{H}, \mathrm{t}, \mathrm{J}_{\mathrm{HH}}=7.5 \mathrm{~Hz}, \mathrm{CH}_{3}\right)$. ${ }^{13} \mathrm{C}\left\{{ }^{1} \mathrm{H}\right\} \mathrm{NMR}\left(\mathrm{CDCl}_{3}\right): \delta 161.5,139.0,121.0,115.8,107.8$, 60.0, 31.4, 27.5, 22.2, 14.5, 13.7. Elemental analysis: found \%C 67.74, \%H 8.70, \% N 7.24; calcd. \%C 67.66, \%H 8.78, \% 7.17.

\subsubsection{Synthesis of ethyl 4-butyl-pyrrole-2-}

carboxylate (1h)

1,3-diimine synthesis followed general procedure using $\mathrm{Ti}$ precatalyst $\mathbf{B}(30.8 \mathrm{mg}, 10 \mathrm{~mol} \%)$, cyclohexylamine $(230 \mu \mathrm{L}, 2$ mmol), 1-hexyne $(115 \mu \mathrm{L}, 1 \mathrm{mmol})$ and heating at $100{ }^{\circ} \mathrm{C}$ for 24 h. Method A: The pyrrole was afforded $(68 \mathrm{mg}, 35 \%)$ as a brown oil. $\mathrm{R}_{f}\left(25 \%\right.$ EtOAc/hexane) $0.46 .{ }^{1} \mathrm{H} \mathrm{NMR}\left(\mathrm{CDCl}_{3}\right): \delta 8.91(1 \mathrm{H}$, br s, N-H pyrrole), $6.77\left(1 \mathrm{H}, \mathrm{d}, \mathrm{J}_{\mathrm{HH}}=1.9 \mathrm{~Hz}, \mathrm{C}-\mathrm{H}\right.$ pyrrole $), 6.74$ $\left(1 \mathrm{H}, \mathrm{d}, \mathrm{J}_{\mathrm{HH}}=1.9 \mathrm{~Hz}, \mathrm{C}-\mathrm{H}\right.$ pyrrole $), 4.31\left(2 \mathrm{H}, \mathrm{q}, \mathrm{J}_{\mathrm{HH}}=7.1 \mathrm{~Hz}\right.$, $\left.\mathrm{CH}_{2}\right), 2.46\left(2 \mathrm{H}, \mathrm{t}, \mathrm{J}_{\mathrm{HH}}=7.5 \mathrm{~Hz}, \mathrm{CH}_{2}\right), 1.52-1.58\left(2 \mathrm{H}, \mathrm{m}, \mathrm{CH}_{2}\right)$, $1.34-1.38\left(5 \mathrm{H}, \mathrm{m}, \mathrm{CH}_{2}\right.$ and $\left.\mathrm{CH}_{3}\right), 0.91\left(3 \mathrm{H}, \mathrm{t}, \mathrm{J}_{\mathrm{HH}}=7.3 \mathrm{~Hz}, \mathrm{CH}_{3}\right)$. ${ }^{13} \mathrm{C}\left\{{ }^{1} \mathrm{H}\right\}$ NMR $\left(\mathrm{CDCl}_{3}\right) \delta 161.2,134.5,128.7,126.5,125.3$, $123.7,119.4,112.4,60.5,14.4$. Elemental analysis: found $\% \mathrm{C}$ 67.07, \% 8 8.66, \% N 7.25; calcd. \% C 67.66, \% H 8.76, \% N 7.17. HRMS (ES) m/z calcd. for $\mathrm{C}_{11} \mathrm{H}_{16} \mathrm{NO}_{2}$ 194.1181, found 194.1185.

4.4.9. Synthesis of ethyl 5-cyclohexyl-pyrrole-2carboxylate $(\mathbf{1} \boldsymbol{i})$

1,3-diimine synthesis followed general procedure using $\mathrm{Ti}$ precatalyst A (32.4 mg, $10 \mathrm{~mol} \%)$, aniline $(180 \mu \mathrm{L}, 2 \mathrm{mmol})$, cyclohexylacetylene $(131 \mu \mathrm{L}, 1 \mathrm{mmol})$ and heating at $100{ }^{\circ} \mathrm{C}$ for $24 \mathrm{~h}$. Method A: The pyrrole was afforded (104 mg, 47\%) as a light orange solid. M.p. 106-107 ${ }^{\circ} \mathrm{C}$. $\mathrm{R}_{f}(25 \% \mathrm{EtOAc/hexane)}$ 0.46. ${ }^{1} \mathrm{H}$ NMR $\left(\mathrm{CDCl}_{3}\right): \delta 8.78(1 \mathrm{H}$, br s, N-H pyrrole $), 6.82(1 \mathrm{H}$, $\mathrm{t}, \mathrm{J}_{\mathrm{HH}}=2.9 \mathrm{~Hz}, \mathrm{C}-\mathrm{H}$ pyrrole $), 5.97\left(1 \mathrm{H}, \mathrm{t}, \mathrm{J}_{\mathrm{HH}}=2.9 \mathrm{~Hz}, \mathrm{C}-\mathrm{H}\right.$ pyrrole), $4.29\left(2 \mathrm{H}, \mathrm{q}, \mathrm{J}_{\mathrm{HH}}=7.3 \mathrm{~Hz}, \mathrm{CH}_{2}\right), 2.57-261(1 \mathrm{H}, \mathrm{m}, \mathrm{C}-\mathrm{H}$ cyclohexyl), 1.98-2.00 (2H, m, C-H cyclohexyl), 1.80-1.83 (2H, $\mathrm{m}, \mathrm{C}-\mathrm{H}$ cyclohexyl), 1.71-1.74 (1H, m, C-H cyclohexyl), 1.21$1.43\left(8 \mathrm{H}, \mathrm{m}, \mathrm{C}-\mathrm{H}\right.$ cyclohexyl, $\left.\mathrm{CH}_{3}\right) .{ }^{13} \mathrm{C}\left\{{ }^{1} \mathrm{H}\right\}$ NMR $\left(\mathrm{CDCl}_{3}\right) \delta$ 161.4, 143.8, 120.9, 115.6, 106.1, 60.0, 36.9, 32.8, 26.1, 25.9, 14.6. HRMS (ES) $\mathrm{m} / \mathrm{z}$ calcd. for $\mathrm{C}_{13} \mathrm{H}_{19} \mathrm{NO}_{2} 221.1416$, found 221.1417.

\subsubsection{Synthesis of ethyl 4-cyclohexyl-pyrrole-2-} carboxylate $(\mathbf{1} \boldsymbol{j})$

1,3-diimine synthesis followed general procedure using $\mathrm{Ti}$ precatalyst $\mathbf{B}(30.8 \mathrm{mg}, 10 \mathrm{~mol} \%)$, cyclohexylamine $(230 \mu \mathrm{L}, 2$ mmol), cyclohexylacetylene $(131 \mu \mathrm{L}, 1 \mathrm{mmol})$ and heating at 100 ${ }^{\circ} \mathrm{C}$ for $24 \mathrm{~h}$. Method A: The pyrrole was afforded (106 mg, 48\%) as a bright orange solid. M.p. $68-69{ }^{\circ} \mathrm{C} . \mathrm{R}_{f}(25 \%$ EtOAc/hexane $)$ 0.37. ${ }^{1} \mathrm{H}$ NMR $\left(\mathrm{CDCl}_{3}\right): \delta 8.86(1 \mathrm{H}$, br s, N-H pyrrole $), 6.80(1 \mathrm{H}$, $\mathrm{t}, \mathrm{J}_{\mathrm{HH}}=2.4 \mathrm{~Hz}, \mathrm{C}-\mathrm{H}$ pyrrole $), 6.75\left(1 \mathrm{H}, \mathrm{t}, \mathrm{J}_{\mathrm{HH}}=2.4 \mathrm{~Hz}, \mathrm{C}-\mathrm{H}\right.$ pyrrole), $4.30\left(2 \mathrm{H}, \mathrm{q}, \mathrm{J}_{\mathrm{HH}}=7.2 \mathrm{~Hz}, \mathrm{CH}_{2}\right), 2.43-249(1 \mathrm{H}, \mathrm{m}, \mathrm{C}-\mathrm{H}$ cyclohexyl), 1.93-1.95 (2H, m, C-H cyclohexyl), 1.77-1.82 $(2 \mathrm{H}$, $\mathrm{m}, \mathrm{C}-\mathrm{H}$ cyclohexyl), 1.66-1.74 (1H, m, C-H cyclohexyl), 1.21$1.43\left(8 \mathrm{H}, \mathrm{m}, \mathrm{C}-\mathrm{H}\right.$ cyclohexyl, $\left.\mathrm{CH}_{3}\right) .{ }^{13} \mathrm{C}\left\{{ }^{1} \mathrm{H}\right\}$ NMR $\left(\mathrm{CDCl}_{3}\right) \delta$ $161.3,133.0,122.4,119.0,113.2,60.2,36.0,34.5,26.5,26.2$, 14.5. HRMS (ES) $\mathrm{m} / \mathrm{z}$ calcd. for $\mathrm{C}_{13} \mathrm{H}_{19} \mathrm{NO}_{2} 221.1416$, found 221.1425 .

\subsubsection{Synthesis of ethyl 4-phenyl-5-methyl-} pyrrole-2-carboxylate (2a)

1,3-diimine synthesis followed general procedure using $\mathrm{Ti}$ precatalyst B (30.8 mg, $10 \mathrm{~mol} \%)$, aniline (180 $\mu \mathrm{L}, 2 \mathrm{mmol}), 1-$ phenylpropyne $(125 \mu \mathrm{L}, 1 \mathrm{mmol})$ and heating at $100{ }^{\circ} \mathrm{C}$ for $48 \mathrm{~h}$. Method A: The pyrrole was afforded (149 mg, 65\%) as a pale yellow solid. M.p. $124-126{ }^{\circ} \mathrm{C}$ (lit. $\left.{ }^{23} \mathrm{Mp}: 125.5{ }^{\circ} \mathrm{C}\right) ; \mathrm{R}_{f}(25 \%$ EtOAc/hexane) $0.31 ;{ }^{1} \mathrm{H}$ NMR $\left(\mathrm{CDCl}_{3}\right) \delta 9.63(1 \mathrm{H}$, br s, N-H pyrrole), 7.41-7.46 (4H, m, Ar-H), 7.26-7.30 (1H, m, Ar-H), 7.07 $\left(1 \mathrm{H}, \mathrm{d}, \mathrm{J}_{\mathrm{HH}}=2.6 \mathrm{~Hz}, \mathrm{C}-\mathrm{H}\right.$ pyrrole $), 4.39\left(2 \mathrm{H}, \mathrm{q}, \mathrm{J}_{\mathrm{HH}}=7.2 \mathrm{~Hz}\right.$, $\left.\mathrm{CH}_{2}\right), 2.49\left(3 \mathrm{H}, \mathrm{s}, \mathrm{CH}_{3}\right), 1.41\left(3 \mathrm{H}, \mathrm{t}, \mathrm{J}_{\mathrm{HH}}=7.2 \mathrm{~Hz}, \mathrm{CH}_{3}\right) ;{ }^{13} \mathrm{C}$ $\left\{{ }^{1} \mathrm{H}\right\}$ NMR $\left(\mathrm{CDCl}_{3}\right) \delta 161.5,135.8130 .4,128.4,127.6,125.8$, $123.7,120.6,115.3,60.2,14.4,12.8$; elemental analysis: found $\% \mathrm{C} 73.38, \% \mathrm{H} 6.52, \% \mathrm{~N} 6.04$; calcd. $\% \mathrm{C} 73.34, \% \mathrm{H} 6.59, \% \mathrm{~N}$ 6.11 . This compound was also characterized by single crystal Xray diffraction.

\subsubsection{Synthesis of ethyl 3,4-diphenyl-pyrrole-2- carboxylate $(\mathbf{2 b})$}

1,3-diimine synthesis followed general procedure using $\mathrm{Ti}$ precatalyst $\mathbf{B}(30.8 \mathrm{mg}, 10 \mathrm{~mol} \%)$, aniline $(180 \mu \mathrm{L}, 2 \mathrm{mmol})$, diphenylacetylene $(178 \mathrm{mg}, 1 \mathrm{mmol})$ and heating at $120{ }^{\circ} \mathrm{C}$ for $60 \mathrm{~h}$. Method A: The pyrrole was afforded (148 mg, 51\%) as a pale yellow solid. M.p. $120-122{ }^{\circ} \mathrm{C}$ (lit. $\left.{ }^{24} \mathrm{Mp}: 118-119{ }^{\circ} \mathrm{C}\right) . \mathrm{R}_{f}$ (25\% EtOAc/hexane) 0.29. ${ }^{1} \mathrm{H}$ NMR $\left(\mathrm{CDCl}_{3}\right): \delta 9.32(1 \mathrm{H}, \mathrm{br} \mathrm{s}$, N-H pyrrole), 7.24-7.27 (5H, m, Ar-H), 7.14-7.18 (3H, m, Ar-H), 7.07-7.13 (3H, m, Ar- H and C-H pyrrole), $4.16\left(2 \mathrm{H}, \mathrm{q}, \mathrm{J}_{\mathrm{HH}}=7.2\right.$ $\left.\mathrm{Hz}, \mathrm{CH}_{2}\right), 1.11-1.14\left(3 \mathrm{H}, \mathrm{t}, \mathrm{J}_{\mathrm{HH}}=7.2 \mathrm{~Hz}, \mathrm{CH}_{3}\right) ;{ }^{13} \mathrm{C}\left\{{ }^{1} \mathrm{H}\right\} \mathrm{NMR}$ $\left(\mathrm{CDCl}_{3}\right): \delta 161.2,134.5,132.9,130.8,129.6,129.3,128.3,128.2$, $128.1,127.4,126.8,120.2,60.2,14.0$. Elemental analysis: found $\% \mathrm{C} 78.39, \% \mathrm{H} 5.81, \% \mathrm{~N} 4.88$; calcd. $\% \mathrm{C} 78.33, \% \mathrm{H} 5.88, \% \mathrm{~N}$ 4.81. This compound was also characterized by single crystal Xray diffraction.

4.4.13. Synthesis of ethyl 4-phenyl-5-(3-tertbutyldimethylsilyloxy)propyl-pyrrole-2-carboxylate (2c)

1,3-diimine synthesis followed general procedure using $\mathrm{Ti}$ precatalyst B (30.8 $\mathrm{mg}, 10 \mathrm{~mol} \%)$, aniline $(180 \mu \mathrm{L}, 2 \mathrm{mmol}), 1-$ (tert-butyldimethylsilyloxy)-5-phenylpent-4-yne (274 mg, 1 mmol) and heating at $100{ }^{\circ} \mathrm{C}$ for $48 \mathrm{~h}$. Method A: The pyrrole was afforded $(97 \mathrm{mg}, 25 \%)$ as a red solid. M.p. $79-81{ }^{\circ} \mathrm{C} . \mathrm{R}_{f}$ (25\% EtOAc/hexane) 0.40. ${ }^{1} \mathrm{H} \mathrm{NMR}\left(\mathrm{CDCl}_{3}\right): \delta 9.35(1 \mathrm{H}, \mathrm{br} \mathrm{s}$, N-H pyrrole), 7.36-7.40 (3H, m, Ar-H), 7.01-7.27 (2H, m, Ar-H), $7.01\left(1 \mathrm{H}, \mathrm{d}, \mathrm{J}_{\mathrm{HH}}=2.9 \mathrm{~Hz}, \mathrm{C}-\mathrm{H}\right.$ pyrrole $), 4.34\left(2 \mathrm{H}, \mathrm{q}, \mathrm{J}_{\mathrm{HH}}=7.1\right.$ $\left.\mathrm{Hz}, \mathrm{CH}_{2}\right), 3.69\left(2 \mathrm{H}, \mathrm{t}, \mathrm{J}_{\mathrm{HH}}=6.1 \mathrm{~Hz}, \mathrm{CH}_{2}\right), 2.89-2.92\left(2 \mathrm{H}, \mathrm{t}, \mathrm{J}_{\mathrm{HH}}=\right.$ $\left.7.3 \mathrm{~Hz}, \mathrm{CH}_{2}\right), 1.87\left(2 \mathrm{H}\right.$, pent, $\left.\mathrm{J}_{\mathrm{HH}}=7.3 \mathrm{~Hz}, \mathrm{CH}_{2}\right), 1.37\left(3 \mathrm{H}, \mathrm{t}, \mathrm{J}_{\mathrm{HH}}\right.$ $\left.=7.1 \mathrm{~Hz}, \mathrm{CH}_{3}\right), 0.91\left(9 \mathrm{H}, \mathrm{s}, \mathrm{CH}_{3}\right), 0.06\left(6 \mathrm{H}, \mathrm{s}, \mathrm{CH}_{3}\right.$-silyl $)$. ${ }^{13} \mathrm{C}\left\{{ }^{1} \mathrm{H}\right\}$ NMR $\left(\mathrm{CDCl}_{3}\right): \delta 161.1,135.9,134.1,128.5,127.9$, 125.9, 123.7, 120.9, 115.3, 62.1 60.1, 31.7, 26.0, 22.9, 18.4, 14.6, -5.3. Elemental analysis: found $\% \mathrm{C} 67.97, \% \mathrm{H} 8.81, \% \mathrm{~N} \mathrm{3.62;}$ calcd. \%C 68.17, \% $8.58, \% \mathrm{~N} 3.61$.

\subsubsection{Synthesis of ethyl 3,4-di(thiophen-2-yl)- pyrrole-2-carboxylate $(\mathbf{2 d})$}

1,3-diimine synthesis followed general procedure using $\mathrm{Ti}$ precatalyst B $(30.8 \mathrm{mg}, 10 \mathrm{~mol} \%)$, aniline $(180 \mu \mathrm{L}, 2 \mathrm{mmol}), 1,2-$ di(thiophene-2-yl)ethyne (190 mg, $1 \mathrm{mmol})$ and heating at 100 ${ }^{\circ} \mathrm{C}$ for $48 \mathrm{~h}$. Method A: The pyrrole was afforded (112 mg, 37\%) as a yellow solid. M.p. $109-111{ }^{\circ} \mathrm{C}$. $\mathrm{R}_{f}(25 \%$ EtOAc/hexane) 0.17. ${ }^{1} \mathrm{H}$ NMR $\left(\mathrm{CDCl}_{3}\right) \delta 9.33(1 \mathrm{H}$, br s, N-H pyrrole $), 7.38(1 \mathrm{H}$, $\mathrm{dd}, \mathrm{J}_{\mathrm{HH}}=5.1 \mathrm{~Hz}, 1.1 \mathrm{~Hz}, \mathrm{C}-\mathrm{H}$ thiophene $), 7.15\left(1 \mathrm{H}, \mathrm{d}, \mathrm{J}_{\mathrm{HH}}=3.3\right.$ $\mathrm{Hz}, \mathrm{C}-\mathrm{H}$ pyrrole $), 7.11\left(1 \mathrm{H}, \mathrm{dd}, \mathrm{J}_{\mathrm{HH}}=5.1 \mathrm{~Hz}, 1.1 \mathrm{~Hz}, \mathrm{C}-\mathrm{H}\right.$ thiophene), $7.07\left(1 \mathrm{H}, \mathrm{dd}, \mathrm{J}_{\mathrm{HH}}=5.1 \mathrm{~Hz}, 3.3 \mathrm{~Hz}, \mathrm{C}-\mathrm{H}\right.$ thiophene), $7.02\left(1 \mathrm{H}, \mathrm{dd}, \mathrm{J}_{\mathrm{HH}}=3.3 \mathrm{~Hz}, 1.1 \mathrm{~Hz}, \mathrm{C}-\mathrm{H}\right.$ thiophene $), 6.91(1 \mathrm{H}, \mathrm{dd}$, $\mathrm{J}_{\mathrm{HH}}=5.1 \mathrm{~Hz}, 3.3 \mathrm{~Hz}, \mathrm{C}-\mathrm{H}$ thiophene $), 6.78\left(1 \mathrm{H}, \mathrm{dd}, \mathrm{J}_{\mathrm{HH}}=3.3 \mathrm{~Hz}\right.$, $1.1 \mathrm{~Hz}, \mathrm{C}-\mathrm{H}$ thiophene), $4.22\left(2 \mathrm{H}, \mathrm{q}, \mathrm{J}_{\mathrm{HH}}=7.2 \mathrm{~Hz}, \mathrm{CH}_{2}\right), 1.19$ $\left(3 \mathrm{H}, \mathrm{t}, \mathrm{J}_{\mathrm{HH}}=7.2 \mathrm{~Hz}, \mathrm{CH}_{3}\right) \cdot{ }^{13} \mathrm{C}\left\{{ }^{1} \mathrm{H}\right\}$ NMR $\left(\mathrm{CDCl}_{3}\right): \delta 160.7$, $136.0,134.3,128.6,127.0,126.6,126.1,124.2,123.8,121.7$, 121.6, 120.8, 119.7, 60.5, 14.0. Elemental analysis: found \%C 59.16, \%H 4.68, \% N 4.51; calcd. \%C 59.38, \%H 4.32, \% 4.62 . This compound was also characterized by single crystal X-ray diffraction.

4.4.15. Synthesis of ethyl 4-(cyclohexen-1-yl)-5methyl-pyrrole-2-carboxylate $(2 e)$ 
1,3-diimine synthesis followed general procedure using $\mathrm{Ti}$ precatalyst B $(30.8 \mathrm{mg}, 10 \mathrm{~mol} \%)$, aniline $(180 \mu \mathrm{L}, 2 \mathrm{mmol}), 1-$ (cyclohex-1-enyl)propyne $(135 \mu \mathrm{L}, 1 \mathrm{mmol})$ and heating at 100 ${ }^{\circ} \mathrm{C}$ for $48 \mathrm{~h}$. Method A: The pyrrole was afforded (142 mg, 61\%) as a light brown solid. M.p. $99-100{ }^{\circ} \mathrm{C} . \mathrm{R}_{f}(25 \%$ EtOAc/hexane) $0.31 .{ }^{1} \mathrm{H}$ NMR $\left(\mathrm{CDCl}_{3}\right) \delta 8.94(1 \mathrm{H}$, br s, N-H pyrrole $), 6.78(1 \mathrm{H}$, $\mathrm{d}, \mathrm{J}_{\mathrm{HH}}=2.8 \mathrm{~Hz}, \mathrm{C}-\mathrm{H}$ pyrrole), 5.67-5.69 $(1 \mathrm{H}, \mathrm{m}, \mathrm{C}-\mathrm{H}$ alkene $), \delta$ $4.27\left(2 \mathrm{H}, \mathrm{q}, \mathrm{J}_{\mathrm{HH}}=7.2 \mathrm{~Hz}, \mathrm{CH}_{2}\right), 2.32\left(3 \mathrm{H}, \mathrm{s}, \mathrm{CH}_{3}\right), 2.24-2.27$ $\left(2 \mathrm{H}, \mathrm{m}, \mathrm{CH}_{2}\right), 2.12-2.16\left(2 \mathrm{H}, \mathrm{m}, \mathrm{CH}_{2}\right), 1.69-1.73\left(2 \mathrm{H}, \mathrm{m}, \mathrm{CH}_{2}\right)$, $1.59-1.63\left(2 \mathrm{H}, \mathrm{m}, \mathrm{CH}_{2}\right), 1.32\left(3 \mathrm{H}, \mathrm{t}, \mathrm{J}_{\mathrm{HH}}=7.2 \mathrm{~Hz}, \mathrm{CH}_{3}\right) .{ }^{13} \mathrm{C}\left\{{ }^{1} \mathrm{H}\right\}$ $\operatorname{NMR}\left(\mathrm{CDCl}_{3}\right): \delta 161.2,134.5,128.7,126.5,125.3,123.7,119.4$, 112.4, 60.5, 14.4. Elemental analysis: found $\% \mathrm{C} 72.13, \% \mathrm{H} 8.13$, $\% \mathrm{~N} 6.08$; calcd. \%C 72.07, \%H 8.21, \%N 6.00. This compound was also characterized by single crystal X-ray diffraction.

\subsubsection{Synthesis of ethyl 4,5-diethyl-pyrrole-2-} carboxylate $(2 f)$

1,3-diimine synthesis followed general procedure using $\mathrm{Ti}$ precatalyst B $(30.8 \mathrm{mg}, 10 \mathrm{~mol} \%)$, aniline $(180 \mu \mathrm{L}, 2 \mathrm{mmol}), 3-$ hexyne $(114 \mu \mathrm{L}, 1 \mathrm{mmol})$ and heating at $100{ }^{\circ} \mathrm{C}$ for $48 \mathrm{~h}$. Method A: The pyrrole was afforded (57 mg, $29 \%$ ) as a brown solid. M.p. 53-54 ${ }^{\circ} \mathrm{C}$ (lit. ${ }^{25} \mathrm{Mp}$ : $\left.60-62{ }^{\circ} \mathrm{C}\right) . \mathrm{R}_{f}\left(25 \%\right.$ EtOAc/hexane) $0.43 .{ }^{1} \mathrm{H}$ $\mathrm{NMR}\left(\mathrm{CDCl}_{3}\right): \delta 8.99(1 \mathrm{H}$, br s, N-H pyrrole $), 6.75\left(1 \mathrm{H}, \mathrm{d}, \mathrm{J}_{\mathrm{HH}}=\right.$ $2.9 \mathrm{~Hz}, \mathrm{C}-\mathrm{H}$ pyrrole $), 4.30\left(2 \mathrm{H}, \mathrm{q}, \mathrm{J}_{\mathrm{HH}}=7.2 \mathrm{~Hz}, \mathrm{CH}_{2}\right), 2.61(2 \mathrm{H}$, $\left.\mathrm{q}, \mathrm{J}_{\mathrm{HH}}=7.7 \mathrm{~Hz}, \mathrm{CH}_{2}\right), 2.40\left(2 \mathrm{H}, \mathrm{q}, \mathrm{J}_{\mathrm{HH}}=7.5 \mathrm{~Hz}, \mathrm{CH}_{2}\right), 1.35(3 \mathrm{H}$, $\left.\mathrm{t}, \mathrm{J}_{\mathrm{HH}}=7.2 \mathrm{~Hz}, \mathrm{CH}_{3}\right), 1.22\left(3 \mathrm{H}, \mathrm{t}, \mathrm{J}_{\mathrm{HH}}=7.7 \mathrm{~Hz}, \mathrm{CH}_{3}\right), 1.17(3 \mathrm{H}, \mathrm{t}$, $\left.\mathrm{J}_{\mathrm{HH}}=7.5 \mathrm{~Hz}, \mathrm{CH}_{3}\right) \cdot{ }^{13} \mathrm{C}\left\{{ }^{1} \mathrm{H}\right\}$ NMR $\left(\mathrm{CDCl}_{3}\right): \delta 161.3,135.8$, 123.6, 119.7, 115.1, 59.9, 19.2, 18.7, 15.4, 14.6, 13.8. Elemental analysis: found \%C 67.85, \%H 8.75, \%N 7.40; calcd. \%C 67.66, $\% \mathrm{H} 8.78, \% \mathrm{~N} 7.17$.

\section{Acknowledgments}

The authors greatly appreciate the financial support of the National Science Foundation (CHE-1265738). The authors would also like to thank Dan Holmes for his help with the NMR experiments.

\section{References and notes}

1. (a) Odom, A. L.; McDaniel, T. J. Acc. Chem. Res. 2015, in press 10.1021/acs.accounts.5b00280. (b) Odom, A. L. Dalton Trans. 2005, 225. (c) Cao, C.; Shi, Y.; Odom, A. L. J. Am. Chem. Soc. 2003, 125, 2880 .

2. (a) Majumder, S.; Gipson, K. R.; Staples, R. J.; Odom. A. L. Adv Synth. Catal. 2009, 351, 2013. (b) Majumder, S.; Gipson, K. R.; Odom, A. L. Org. Lett. 2009, 11, 4720. (c) Majumder, S.; Odom, A. L. Tetrahedron 2010, 66, 3152. (d) Dissanayake, A. A.; Odom, A. L. Tetrahedron 2012, 68, 807. (e) Dissanayake, A. A.; Staples, R. J.; Odom, A. L. Adv. Synth. Catal. 2014, 356, 1811.

3. Li, Y.; Turnas, A.; Ciszewski, J. T.; Odom, A. L. Inorg. Chem. 2002, 41, 6298 .

4. Ramanathan, B.; Keith, A. J.; Armstrong, D.; Odom, A. L. Org. Lett. 2004, 6, 2957.

5. Barnea, E.; Majumder, S.; Staples, R. J.; Odom. A. L. Organometallics 2009, 28, 3876.

6. Recent reviews on pyrrole synthesis: (a) Estévez, V.; Villacampa, M.; Menéndez, J. C. Chem. Soc. Rev. 2010, 39, 4402. (b) Schmuck, C.; Rupprecht, D. Synthesis 2007, 3095.
7. The original Hantzsch synthesis was a two-component reaction between ethyl $\beta$-aminocrontonate and $\alpha$-halocarbonyls. See Roomi, M. W.; MacDonald, S. F. Can. J. Chem. 1970, 48, 1689.

8. Khaghaninejad, S.; Heravi, M. M. Adv. Heterocyclic Chem. 2014, 111,95 .

9. Mataka, S.; Takahashi, K.; Tsuda, Y.; Tashiro, M. Synthesis 1982, 157.

10. Harris, S. A.; Ciszewski, J. T.; Odom, A. L. Inorg. Chem. 2001, 40, 1987-1988.

11. (a) Shi, Y.; Hall, C.; Ciszewski, J. T.; Cao, C.; Odom, A. L. Chem. Commun. 2003, 586. (b) Novak, A.; Blake, A. J.; Wilson, C.; Love, J. B. Chem. Comm. 2002, 2796

12. (a) Swartz, D. L. II; Staples, R. J.; Odom, A. L. Dalton Trans. 2011, 40, 7762. (b) DiFranco, S. A.; Maciulis, N. A.; Staples, R. J.; Batrice, R. J.; Odom, A. L. Inorg. Chem. 2012, 51, 1187. (c) Bemowski, R. D.; Singh, A. K.; Bajorek, B. J.; DePorre, Y.; Odom, A. L. Dalton Trans. 2014, 43, 12299.

13. The regioselectivity in Eq. 2 is $3: 1$, and if $\mathbf{B}$ is used in place of $\mathbf{A}$ the ratio is $1: 1$. The regioselectivity in Eq. 3 is $11: 1$, and if $\mathbf{A}$ is used in place of $\mathbf{B}$ then the ratio is $9: 1$. Use of aniline as the amine gives the major product in Eq. 2; whereas use of cyclohexylamine gives the major product shown in Eq. 3 . Consequently, the amine and catalyst choice act together on determining regioselectivity with alkyl-substituted alkynes.

14. Ciaccia, M.; Pilati, S.; Cacciapaglia, R.; Mandolin, L.; Di Stefano, S. Org. Biomol. Chem. 2014, 12, 3282-3287.

15. Imine formation involving two different alkyl amines has been found to favor the amine with higher hyperconjugation, e.g., isopropylamine displaces $n$-butylamine. Consequently, it is possible that tert-butylamine will displace any of the other amine sources in the reaction mixture, if 1,3-diimines behave similarly. Ciaccia, M.; Caccipaglia, R.; Mencarelli, P.; Mandolini, L; Di Stefano, S. Chem. Sci. 2013, 4, 2253-2261.

16. Ring closure of the hemiaminal has been proposed as the rate determining step in the Paal-Knorr synthesis. Mothana, B.; Boyd, R. J. THEOCHEM 2007, 811, 97.

17. For discussions of Curtin-Hammett kinetics see (a) Seeman, J. I. Chem. Rev. 1983, 83, 83-134. (b) Follett, A. D.; McNeill, K. J. Am. Chem. Soc. 2005, 127, 844-845.

18. Li, A.; Turnas, A.; Ciszewski, J. T.; Odom, A. L. Inorg. Chem. 2002, 41, 6298-6306.

19. Littler, B. J.; Miller, M. A.; Hung, C-H.; Wagner, R. W.; O’Shea, D. F.; Boyle, P. D.; Lindsey, J. S. J. Org. Chem. 1999, 64, 1391-1396.

20. (a) Mujkic, M.; Lentz, D. Dalton Trans. 2012, 41, 839-849. (b) Ban, H. S.; Minegishi, H.; Shimizu, K.; Maruyama, M.; Yasui, Y.; Nakamura, H. Chem. Med. Chem. 2010, 5, 1236-1241. (c) Marshall, J, A.; Dehoff, B. S. J. Org. Chem. 1986, 51, 863. (d) Mio, M. J.; Kopel, L. C.; Braun, J. B.; Gadzikwa, T. L.; Hull, K. L.; Brisbois, R. G.; Markworth, C. J.; Grieco, P. A. Org. Lett. 2002, 4, 3199-3202. (e) Aksin-Artok, Ö, Krause, N. Adv. Synth. Catal. 2011, 353, 385.

21. Gokel, G. W.; Widera, R. P.; Weber, W. P. Org. Synth. 1976, 55, 96.

22. Handy, S. T.; Zhang, Y.; Bregman, H. J. Org. Chem. 2004, 69, 2362-2366

23. Schonfelder, W.; Spora, L.; Hemetsberger, H. J. Chem. Res. (s), 1977, 247.

24. Gupton, J. T.; Krumper, K. E.; Burnham, B. S.; Dwornik, K. A.; Petrich, S. A.; Du, K. X.; Bruce, M. A.; Vu, P.; Vargas, M.; Keertikar, K. M.; Hosein, K. N.; Jones, C. R.; Sikorski, J. A. Tetrahedron 1998, 54, 5075-5088.

25. Chapman, R. A.; Roomi, M. W.; Morton, T. C.; Krajcarski, D. T.; Macdonald, S. F. Can. J. Chem. 1971, 49, 3544-3564. 


\section{Graphical Abstract}

One-pot synthesis of pyrroles using a titanium-catalyzed multicomponent coupling procedure

Cody M. Pasko, Amila A. Dissanayake, Brennan S. Billow and Aaron L. Odom*

Michigan State University, Department of Chemistry, 578 S. Shaw Ln, East Lansing, MI 48824

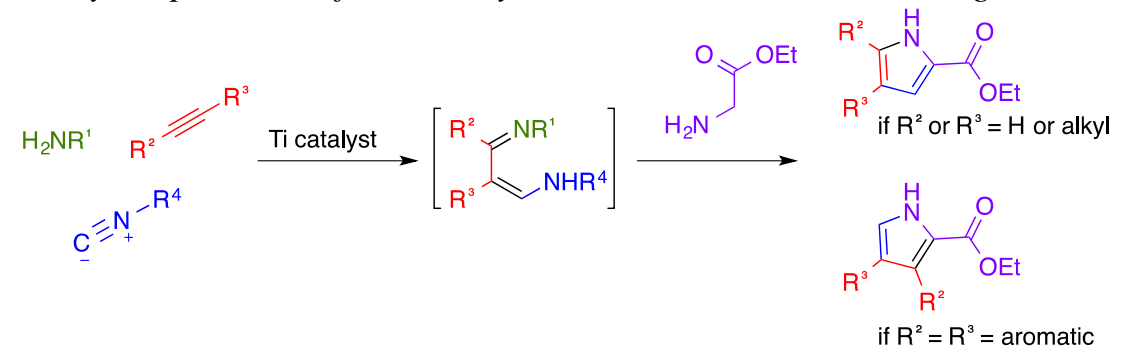

